\title{
Erratum to: "Fluidic Diode" for Passive Unidirectional Liquid Transport Bioinspired by the Spermathecae of Fleas
}

\author{
Gerda Buchberger ${ }^{1 *}$, Alexander Kogler ${ }^{2}$, Agnes Weth ${ }^{1}$, Richard Baumgartner ${ }^{2}$, Philipp Comanns ${ }^{3}$, \\ Siegfried Bauer ${ }^{2}$, Werner Baumgartner ${ }^{1}$ \\ 1. Institute of Biomedical Mechatronics, Johannes Kepler University Linz, Altenberger Str. 69, A-4040 Linz, Austria \\ 2. Institute of Experimental Physics, Department of Soft Matter Physics, Johannes Kepler University Linz, Altenberger Str. 69, A-4040 \\ Linz, Austria \\ 3. Institute of Biology II, RWTH Aachen University, Worringerweg 3, D-52074 Aachen, Germany
}

Copyright $\odot$ The author(s) 2020. This article is published with open access at Springerlink.com.

Erratum to: J Bionic Eng (2018) 15(1): 42-56

https://doi.org/10.1007/s42235-017-0003-7

The article "“Fluidic Diode” for Passive Unidirectional Liquid Transport Bioinspired by the Spermathecae of Fleas", written by Gerda Buchberger, Alexander Kogler, Agnes Weth, Richard Baumgartner, Philipp Comanns, Siegfried Bauer, Werner Baumgartner, was originally published electronically on the publisher's internet portal (currently SpringerLink) on January 20th 2018 without open access. With the author(s)' decision to opt for Open Choice the copyright of the article changed in October 2020 to (c) The Author(s) 2020 and the article is forthwith distributed under the terms of the Creative Commons Attribution 4.0 International License (http://creativecommons.org/licenses/by/4.0/), which permits use, duplication, adaptation, distribution and reproduction in any medium or format, as long as you give appropriate credit to the original author(s) and the source, provide a link to the Creative Commons license and indicate if changes were made.

The original article has been corrected.

The original article can be found online at https://doi.org/10.1007/s42235-017-0003-7.

Open Access This article is distributed under the terms of the Creative Commons Attribution 4.0 International License (http://creativecommons.org/licenses/by/4.0/), which permits use, duplication, adaptation, distribution and reproduction in any medium or format, as long as you give appropriate credit to the original author(s) and the source, provide a link to the Creative Commons license and indicate if changes were made.

\footnotetext{
*Corresponding author: Gerda Buchberger

E-mail: gerda.buchberger@jku.at
} 